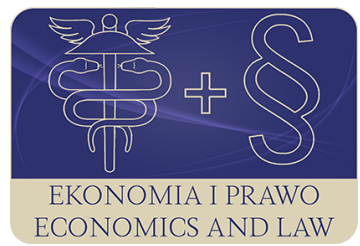

EKONOMIA I PRAWO. ECONOMICS AND LAW

Volume 16, Issue 2, June 2017

p-ISSN 1898-2255, e-ISSN 2392-1625

www.economicsandlaw.pl

ORIGINAL ARTICLE

received 13.06.2017; revised 25.06.2017; accepted 30.06.2017

Citation: Mazurkiewicz, A. (2017). Shaping the career of a talented employee in achieving competitive advantage by modern companies. Ekonomia i Prawo. Ecomomics and Law, 16(2): 159-169. doi:10.12775/EiP.2017.011.

\title{
Shaping the career of a talented employee in achieving competitive advantage by modern companies
}

\author{
ANNA MAZURKIEWICZ \\ University of Rzeszów, Faculty of Economics, Department of Economic Investments and Strategic \\ Management, ul. Rejtana 16c, 35-959 Rzeszów, Poland \\ $\square$ annam@ur.edu.pl
}

\begin{abstract}
Motivation: In a knowledge-based economy, the competitiveness of companies is increasingly determined by an ability to use their resources to respond to changes. A particular role is attributed to intangible assets which become basic, while other factors are beginning to take on a complementary role. In today's business the talent - a talented employee s strategically important.

However, resources are not valuable in themselves, but they are important in terms of activities aimed at achieving a competitive advantage. Recruiting and retaining talented employees is one of the biggest challenges in many businesses because of their outstandingness. Taking into account their specific characteristics, needs and expectations, an ability to pursue a career becomes the key issue.

Aim: The purpose of this article is to show the importance of career talents for the competitive advantage of a modern company. Its realization will be made by presenting the talent as a source of competitive advantage. The importance of contemporary career models for talented individuals as well as the company perspective will be shown.

Results: Traditional organizational careers are not a thing of the past - careers continue to be a means to accomplish strategic goals of the organization, especially during the ongoing talent war. Temporarily employment relationships and the high mobility of talented individuals mean that for this group of employees organizations should strive to build long-term relationships as a result of managing their careers within the organization. Such career development will contribute to the company's strategic intentions.
\end{abstract}


Keywords: the talent; talent management; career management; modern career models; competitive advantage

JEL: M12; M51; M53

\section{Introduction}

Increasing competition in world markets makes a growing interest in achieving and maintaining competitive advantage by a company. This advantage is perceived as a relative category that refers to the position of a competing business and distinguishes it from the rest. It means achieving an overriding position on competitors by offering purchasers lower prices for equivalent benefits or providing unique advantages that compensate for higher prices (Porter, 1998, p. xxii).

In a time of increasing globalization, keeping competitive advantage is becoming more and more difficult (Švárová \& Vrchota, 2013, p. 688), it requires flexibility in action and uncertainty management. Competitor pressure, comparability and duplication of resources (Sołoducho-Pelc, 2014, p. 272) lead to the search for sources of advantage in the company's internal resources, which are nowadays of a high priority (cf. Wernerfelt, 1984, pp. 171-180; Barney, 1991, pp. 99-120). The importance of intangibles in particular is growing.

Resources, in order to become a source of competitive advantage, should be valuable, rare, difficult to imitate, and should not have substitutes (Barney, 1991, pp. 99-120). Valuable resources make it possible to take advantage of opportunities and/or reduce risks in the environment. They allow an effective and efficient operation. However, to be a source of advantage, they should be rare, i.e. they cannot have a large number of current or potential competitors at their disposal. The passage of time results in a decreasing advantage due to the actions of competitors, so strategically important resources should be difficult to imitate or substitute. Their way of organizing is gaining momentum when they are imitated. Gubman (1998, p. 15) stresses that the only resource that is necessary and sufficient for the implementation of the strategy is the staff. As a critical resource Zuboff (1988, p. 402) points to talented employees at every level of the organization (Guthridge et al., 2008, p. 55).

Reaching the potential of these employees depends very much on external factors - it requires creating favorable conditions for their actions. Resources are not valuable in themselves, but they are important in terms of actions aimed at achieving a competitive advantage. Taking into account the specific characteristics of talented individuals, the key issue becomes an ability to pursue a career that is adequate to the needs and expectations of the talents, and at the same time to support the strategic intentions of the organization. Although today the basic burden for the shape and progress of a career lies with an individual, it is planned and managed in the organization.

The aim of this article is to show the importance of the career of talented individuals for the competitive advantage of the modern companies. Its realiza- 
tion will be made by presenting talent as a source of competitive advantage. The importance of contemporary career models for talented individuals as well as from the perspective of the company will be shown.

\section{Research method}

This article is of a review nature. The considerations have been made on the basis of an analysis of the literature, primarily in the areas of management sciences: strategic management and human resources management, in which the literature review on talent management and career management has been reviewed. An important supplement have been the inscriptions formulated in psychology literature. New trends in employee career management have been confronted with the assumptions adopted in talent management, which have been taken into account in the strategic context of the organization's functioning.

\section{Talent as a source of competitive advantage}

The talent in an organization is identified with impressive, outstanding achievements, and it is considered in the context of innate potential for achievement (Simonton, 2011, p. 639). The talent as a person of great potential far exceeds the expectations of an organization now and is also expected to be in the future (Berger \& Berger, 2011, p. 5). Tansley et al. (2006, p. 2) view the talent as a complex set of skills, knowledge, cognitive abilities, and employee potential. Their values and occupational preferences are also important. Talent is also interpreted as the sum of a person's abilities, inner gifts, skills, knowledge, experience, intelligence, judgment, attitudes, character, and endeavor. This sum also includes an ability to learn and develop. These characteristics result in an outstanding value (Michaels et al., 2001, p. xii). Therefore, the selected employees, not all ones should be described as talented.

The interpretations presented prove that the concept of talent accentuates both its current achievements and its potential. Having superior capabilities enables to achieve high performance, create added value, and keep an organization competitive. An employee who is particularly affected by an increase in the value of the organization - Abrudan and Matei (2009, p. 28) argues that talented employees generate up to three times higher earnings than the other employees. Buckingham and Vosburgh (2001, p. 21) claim that the talent should relate to repetitive patterns of thinking, feeling and behavior that can be applied productively. The talent is an entity that meets the criteria for its above-average identification, does not necessarily represent the highest degree.

The interpretation presented shows that the talent fulfills all criteria of a strategic nature - it is valuable, rare and difficult to imitate (this criterion is the most significant) (Lewis \& Heckman, 2006, p. 145), and does not have substitutes. Talented individuals have a lot of potential, have innate abilities, knowledge and skills valuable to meet the needs of an organization, are highly motivated 
internally and achieve superior results. Using their potential and achieving high results requires further consideration of their needs and expectations of an organization (Uren, 2011, p. 32), which enables managers to tailor their solutions to their individual preferences. Properly planned and implemented actions contribute to motivational growth and prevent the departure of talent from the organization (Branham, 2005, p. 3). On the contrary, the discrepancy between what the talented individuals expect and what is attractive to them is conducive to improper development of talent management programs including remuneration, development, career planning, and job customization.

The talent management activities are becoming increasingly important. The strategic importance of the talent is reflected in the process of improving the organization's strategy and an impact on the organization's performance (Paauwe \& Richardson, 1997, pp. 257-262). The key issue is identifying key positions that contribute to achieving lasting competitive advantage, as well as the development of talented individuals able to embrace these positions, and improving the employment structure to improve key positions by competent bodies and ensure their continued commitment to the organization (Collings \& Mellahi, 2009, p. 305).

Organization results are shaped by individual results, which in turn represent the employee's ability, motivation and opportunities (Boselie et al., 2005, p. 72). Identifying the unit as a talented person is associated with having a high - above average level of expected ability, and identifying key positions means that it is creating opportunities for the organization's performance. Hence, motivation becomes essential (Collings \& Mellahi, 2009, p. 310). It is concerned with the physical, psychological and social mechanisms that make it possible to achieve goals and meet individual needs (Tuncel et al., 2016, p. 244). It is the inner strength of a person which the level, direction and endurance of the effort are dependent on (Schermerhorn, 2012, p. 308). It stimulates, directs and maintains targeted actions (Mitchell, 1982, p. 81), leads to success and satisfaction (Tuncel et al., 2016, p. 244). The importance of motivational factors in the individual's achievements is defined as the key one - being systematic, hard work for many years, effort, determination are for the development of talent more important than innate features (Ericsson \& Charness, 1994, p. 729).

Internal motivation is the basis for the efficient and effective work of the employee, hence the conditions for its induction should be created. It is, therefore, necessary to recognize the needs of talented individuals, which will counteract the diversion of talent from the organization and enable the formation of individual career paths. The low level of satisfaction of individual needs results in many negative consequences. Individuals who perceive a strong relationship between individual and organizational values are more committed to the organization (Collings \& Mellahi, 2009, p. 205). The employee involved is characterized by willingness to sacrifice, determination in overcoming difficulties, inquisitiveness, responsibility and openness to change. He is positively oriented 
towards the organization and its values, enthusiastic about his work, works with others to improve performance for the organization. He cares about future and is ready to make the effort to succeed. He is emotionally connected with the organization and can adapt his goals to the organization's goals (Katyayani \& Nirmala Rani, 2016, pp. 86-88).

An ability to define the needs of talents, to discover different sources of talent, to develop talent, to deploy it in ways that engage and connect people around accomplishing important goals, and linking these skills with organizational strategy and involving talents in operational activities, makes them a source of long-term competitive advantage (Cheese et al., 2008, p. 10). In turn, the loss or absence of talent significantly slows down the development of the company due to its disproportionate influence on the current and future performance of the organization (Berger \& Berger, 2004, p. 4). Missing talent is perceived as the main threat to business expansion.

Generally speaking, Boudreau (2003, p. 3) points out that talent management contributes to financial gain, long-term competitive advantage, and goes beyond traditional organizational success - to meet the needs of individual stakeholder groups now and in the future.

Talented employees are, according to Boudreau and Ramstad (2005, pp. 17-26), equally important to the organization's success as finance or marketing. Authors emphasize the role of talent management for achieving strategic success, pointing to three key areas that are included in resource decision making: efficiency, effectiveness, and impact. In their opinion, at present organizations focus primarily on measuring efficiency and effectiveness, but rarely include the influence on investment impact on quality and availability (quantity) of talent to increase strategic success. Hence, the key issue is the development of talented workers, which gives them a great potential.

\section{Career of the talented individual and its significance for the company}

The eminence of the talents and the superior performance of the talented individuals give rise to great interest in the talents in organizations ('The War for Talent'). The ability to identify and properly use their potential as well as the development of this potential becomes one of the fundamental challenges. Creation an ability to pursue a career for the talents not only contributes to the organization's long-term benefits, it also fosters self-fulfillment. The key role in talent development is attributed to self-activity (Duckworth et al., 2007, p. 1088; Gagné, 2000, p. 69; Tsay \& Banaji, 2011, p. 464).

At the same time this activity requires the formation of a talented individual. A traditional career was characteristic for organizations operating in relatively stable conditions, where its course was relatively predictable. The main determinant of success was the promotion, which was realized mainly in the vertical 
structures. Career was conducted in a few organizations (one, two), and the organization was responsible for the organization (Sullivan, 1999, p. 458).

Changing patterns of production and consumption, the ongoing technological progress, as well as changes in the labor market and in the employment relationship - between the individual and the organization (transition from long-term to short-term, from dependency to subjectivity) make the career today is perceived to a greater extent as the property of the individual a counter-position to the traditional understanding of it as a property of an organization or profession. Responsibility for its shape and progress was shifted towards the individual. However, it is still planned and managed in the organization (Baruch, 2004, pp. 58-73).

Nowadays career has a subjective coloring, a person gives it an individual meaning. This observation is particularly relevant for outstanding individuals who are aware of their strengths and are willing to leave the organization if they are not provided with the possibility of pursuing their individual goals and aspirations. It is, therefore, necessary to take into account the needs and expectations of talents in the organization's strategic intentions, which is to adapt the practices to individual preferences. Properly planned and implemented actions contribute to increased motivation and allow retention of talented workers who are a very mobile group.

The talents leaving represent a serious threat in the context of quantitative and qualitative deficiencies in human capital. The company loses not only valuable and scarce resources, but can be used by its competitors, which is a risk of losing a competitive advantage. That is why it is important to strengthen their organizational commitment.

New career models include a variety of choices - vertical, horizontal, targeted to other individual goals. Career paths are created at this time and space that will be recognize as beneficial by an individual. Also the direction of career and the interpretation of success have an individual dimension. In this context, the importance of protean career and boundaryless career is emphasized.

The protean career is defined as self-managed, based on individually defined goals, covering the whole living space, driven by psychological success (Briscoe \& Hall, 2006, p. 6). It is identified by a frequent change, inventive own, independent work (Hall, 2002, p. 4). It represents a career that reflects freedom, independent career management, and choices based on personal values (Briscoe \& Hall, 2006, p. 6). This model provides the freedom and independence of action and the variety of experiences that are the basis for further professional development. It exposes the importance of the potential of the employee, which is of particular importance for talented individuals.

Due to the increasing permeability of the organization's borders, boundaryless career is becoming increasingly important. It is characterized as unbound, unrelated to one organization, not characterized by an orderly sequence, to a lesser degree by vertical coordination and stability (Briscoe \& Hall, 2006, p. 6). Employees who pursue boundaryless careers have greater independence 
from the employer than with traditional careers. This model is suitable for talented individuals for whom finding a job with another employer is not problematic because of their high value and high mobility at the same time. On the one hand, boundaryless career creates many opportunities for professional development, which is important for the talent, but on the other hand it is associated with negative consequences for both employees (including lack of stability of employment) and for organizations, especially the loss of strategically valuable resources. Making a boundaryless career is a big challenge for organizations where talent management is strategic.

The answer to this challenge is to provide the opportunity to pursue a career within the organization, related to self-management skills, to ensure the realization of personal values, interpersonal development (the protean career). It is imperative to focus on individual performance and individual responsibility. At the same time, given that talent generates a lot of company performance and is a source of competitive advantage, it is important to create conditions for intra-organization movements and to offer many career management practices such as succession planning, coaching, mentoring, rotation, development plans. individual, information on opportunities for career development, and others (De Vos \& Dries, 2013, pp. 1816-1831).

These activities enable self-realization of the talents, and when are tailored to individual needs they encourage greater commitment to the organization. At the same time, they provide support in learning and self-development and in pursuit of goals in a direction chosen by the individual. They satisfy the need for self-esteem, which strengthens the sense of worth and dignity. They work positively on employees' attitudes towards work, increase initiative and willingness to work, motivate them to improve their skills. They have a beneficial effect on the morale of the workers, the relationships they have between them as well as the atmosphere at work.

Implementation of a career in an organization facilitates personal and professional development without having to change an employer. It favors the reduction of conflicts between the personal and professional goals of employees and the demands of the organizational role, which conflicts are destructive the consequences of which may be stress, social imbalance, interpersonal misconceptions. To a greater extent, the personal and professional goals of talented individuals and the resulting organizational tasks are convergent, the stronger is their motivation, which is important for the results achieved and the strategic goals of the company.

On the basis of the above considerations it can be stated that, in the case of talented individuals, the attention should first focus on the issues that characterize the protean career. The issues addressed in the subject matter of a boundaryless career, however, belong to the organization. Such an approach will help to meet the needs of talented individuals, prevent them from leaving, and create opportunities for their potential and development, while at the same time contributing to the strategic intentions of the organization. 


\section{Conclusion}

The characteristics of talented individuals, but also the conditions created by a company, make talents characterized by outstanding achievements, which is important for performance at organizational level. Talent is a source of competitive advantage because of its disproportionate impact on current and future performance of the organization.

Talent individuals are characterized by above average potential for development - professional and personal one. Utilizing the potential of a company requires support from the organization by providing a variety of development opportunities. The needs and aspirations of talented individuals prove that the key issue in this area is to create opportunities to pursue a career. At the same time the high mobility of this group of employees stresses the need to tie them up with the organization.

In the process of shaping the careers of talented individuals there is a need to take individual aspirations into consideration, which enables the boundaryless career which is primarily responsible for the individual as its implementer. At the same time, today's careers are not completely limitless because they are implemented in a specific, formal organizational context. This context influences the individual's actions (in a positive or negative way), which is reflected in the level of achievement. Providing conditions to pursue a career in an organization creates a bond of talented individuals to the organization, allowing it to protect its valuable resources.

The issue of traditional organizational careers is still up-to-date - careers are the means to achieve a company's strategic goals. The interest in it undoubtedly strengthens talent management. With regard to this group of employees, it becomes necessary to apply such management practices to their careers to keep them in the organization and benefit from their creative potential considering the current and future needs of the organization. Therefore, the career of a talented individual is more protean than a boundaryless, thus enabling the talent to build a competitive advantage for the organization.

\section{References}

Abrudan, M.M., \& Matei, M.C. (2009). Talent management — a strategic priority. Annals of the University of Oradea. Economic Sciences, 18(4).

Barney, J.B. (1991). Firm resources and sustained competitive advantage. Journal of Management, 17(1). doi:10.1016/S0742-3322(00)17018-4.

Baruch, Y. (2004). Transforming careers: from linear to multidirectional career paths. Organizational and individual perspectives. Career Development International, 9(1). doi:10.1108/13620430410518147.

Berger, L.A., \& Berger, D.R. (2004). The talent management handbook: creating organizational excellence by identifying, developing, and promoting your best people. New York: McGraw-Hill. 
Berger, L.A., \& Berger, D.R. (2011). The talent management handbook: creating a sustainable competitive advantage by selecting, developing, and promoting the best people. New York: McGraw-Hill.

Boselie, P., Dietz, G., \& Boon, C. (2005). Commonalities and contradictions in HRM and performance research. Human Resource Management Journal, 15(3). doi:10.1111/j.1748-8583.2005.tb00154.x.

Branham, L. (2005). The 7 hidden reasons employee leave: how to recognize the subtle signs and act before it's too late. New York: AMACOM.

Briscoe, J.P., \& Hall, D.T. (2006). The interplay of boundaryless and protean careers: Combinations and implications. Journal of Vocational Behavior, 69(1). doi:10.1016/j.jvb.2005.09.002.

Buckingham, M., \& Vosburgh, R.M. (2001). The 21st century human resources function: it's the talent, stupid! Human Resource Planning, 24(4).

Boudreau, J.W. (2003). Sustainability and the talentship paradigm: strategic human resource management beyond the bottom line. CAHRS Working Paper, 03-21.

Boudreau, J.W., \& Ramstad, P.M. (2005). Talentship and the evolution of human resource management: from 'professional practices' to 'strategic talent decision science'. Human Resource Planning Journal, 28(2).

Cheese, P., Thomas, R.J., \& Craig, E. (2008). Talent powered organization. Strategies for globalization, talent management, and high performance. London-Philadelphia: Kogan Page.

Collings, D.G., \& Mellahi, K. (2009). Strategic talent management: a review and research agenda. Human Resource Management Review, 19(4). doi:10.1016/j.hrmr.2009.04.001.

De Vos, A., \& Dries, N. (2013). Applying a talent management lens to career management: the role of human capital composition and continuity. International Journal of Human Resource Management, 24(9). doi:10.1080/09585192 .2013.777537.

Duckworth, A.L., Peterson, C., Matthews, M.D., \& Kelly D.R. (2007). Grit: perseverance and passion for long-term goals. Journal of Personality and Social Psychology, 92(6). doi:10.1037/0022-3514.92.6.1087.

Ericsson, K. A., \& Charness, N. (1994). Expert performance: Its structure and acquisition. American Psychologist, 49(8). doi:10.1037/0003-066X.49.8.725.

Gagné, F. (2000). Understanding the Complex Choreography of Talent Development. In K.A. Heller, F.J. Mönks, R.J. Sternberg, \& R.F. Subotnik (Eds.), International Handbook of Giftedness and Talent. Oxford: Elsevier.

Gubman, E.L. (1998). The talent solution: Aligning strategy and people to achieve extraordinary results. New York: McGraw-Hill.

Guthridge, M., Komm, A.B., \& Lawson, E. (2008). Making talent a strategic priority. The McKinsey Quarterly, 1.

Hall, D.T. (2002). Careers in and out of organizations. Thousand Oaks: Sage Publications. 
Katyayani, J., \& Nirmala Rani, T.N. (2016). A study on employee engagement among the employees of power sector with special reference to APSPDCL. International Education \& Research Journal, 2(7).

Lewis, R.E., \& Heckman, R.J. (2006). Talent management: A critical review. Human Resource Management Review, 16. doi:10.1016/j.hrmr.2006.03.001.

Michaels, E., Handfield-Jones, H., \& Axelrod, B. (2001). The war for talent. Boston: Harvard Business School Press.

Mitchell, T.R. (1982). Motivation: New Direction for Theory, Research, and Practice. Academy of Management Review, 7(1). doi:10.5465/ AMR.1982.4285467.

Paauwe, J., \& Richardson, R. (1997). Introduction special issue on HRM and performance. International Journal of Human Resource Management, 8(3). doi:10.1080/095851997341621.

Porter, M.E. (1998). Competitive advantage: creating and sustaining superior performance. New York: The Free Press.

Schermerhorn, J.R. (2012). Exploring Management. Hoboken: John Wiley \& Sons.

Simonton, D.K. (2011). Exceptional talent and genius. In T. Chamorro-Premuzic, S. von Stumm \& A. Furnham (Eds.). The Wiley-Blackwell handbook of individual differences. Retrieved 13.06.2017 from http://www.blackwellreference.com.

Soloducho-Pelc, L. (2014). Competitive advantage: the courage in formulating objectives and expansiveness of a strategy. Procedia - Social and Behavioral Sciences, 150. doi:10.1016/j.sbspro.2014.09.058.

Sullivan, S. E. (1999). The changing nature of careers: a review and research agenda. Journal of Management, 25(3). doi:10.1177/014920639902500308.

Švárová, M., \& Vrchota, J. (2014). Influence of competitive advantage on formulation business strategy. Procedia Economics and Finance, 12. doi:10.1016/ s2212-5671(14)00394-3.

Tansley, C., Harris, L., Stewart, J., \& Turner, P. (2006). Talent management: understanding the dimensions. Change Agenda. London: CIPD.

Tsay, C.J., \& Banaji, M.R. (2011). Naturals and strivers: preferences and beliefs about sources of achievement. Journal of Experimental Social Psychology, 47. doi:10.1016/j.jesp.2010.12.010.

Tuncel, E., Sadikoglu, S., \& Memmedova, K. (2016). Statistical reasoning of impact of motivation on students' achievement in foreign language learning. Procedia Computer Science, 102. doi:10.1016/j.procs.2016.09.397.

Uren, L. (2011). What talent wants: the journey to talent segmentation. Strategic HR Review, 10(6). doi:10.1108/14754391111172805.

Wernerfelt, B. (1984). A resource-based view of the firm. Strategic Management Journal, 5(2). doi:10.1002/smj.4250050207.

Zuboff, S. (1988). In the age of the smart machine: the future of work and power. New York: Basic Books. 


\section{Acknowledgements}

Author contributions: author has given an approval to the final version of the article.

Funding: this research was fully funded by the University of Rzeszów, Faculty of Economics sources. 
